\title{
The Battle Hymn OF THE REPUbLic
}

As published in the New-York Tribune, January 14, 1862

Mine eyes have seen the glory of the coming of the Lord:

$\mathrm{He}$ is trampling out the vintage where the grapes of wrath are stored;

He hath loosed the fateful lightning of His terrible swift sword:

His truth is marching on.

I have seen him in the watch-fires of a hundred circling camps;

They have builded Him an altar in the evening dews and damps;

I have read his righteous sentence by the dim and flaring lamps:

His day is marching on.

I have read a fiery gospel writ in burnished rows of steel:

"As ye deal with my contemners, so with you my grace shall deal;

Let the Hero, born of woman, crush the serpent with his heel,

Since God is marching on."

He has sounded forth the trumpet that shall never call retreat;

He is sifting out the hearts of men before His judgment-seat:

Oh, be swift, my soul, to answer Him! be jubilant, my feet!

Our God is marching on.

In the beauty of the lilies Christ was born across the sea,

With a glory in his bosom that transfigures you and me:

As he died to make men holy, let us die to make men free,

While God is marching on. 

A Fiery Gospel 
